\title{
The Monumental Olive Trees as Biocultural Heritage of Mediterranean Landscapes: The Case Study of Sicily
}

\author{
Rosario Schicchi ${ }^{1}$, Claudia Speciale ${ }^{2, *}$, Filippo Amato ${ }^{1}$, Giuseppe Bazan ${ }^{3}{ }^{\circ}$, Giuseppe Di Noto ${ }^{1}$, \\ Pasquale Marino ${ }^{4}\left(\mathbb{D}\right.$, Pippo Ricciardo ${ }^{5}$ and Anna Geraci ${ }^{3}$ \\ 1 Department of Agricultural, Food and Forest Sciences (SAAF), University of Palermo, 90128 Palermo, Italy; \\ rosario.schicchi@unipa.it (R.S.); filippoamato@alice.it (F.A.); giuseppe.dinoto1@gmail.com (G.D.N.) \\ 2 Departamento de Ciencias Históricas, Facultad de Geografía e Historia, Universidad de Las Palmas de Gran \\ Canaria, 35004 Las Palmas de Gran Canaria, Spain \\ 3 Department of Biological, Chemical and Pharmaceutical Sciences and Technologies (STEBICEF), \\ University of Palermo, 90123 Palermo, Italy; giuseppe.bazan@unipa.it (G.B.); anna.geraci@unipa.it (A.G.) \\ 4 Bona Furtuna LLC, Los Gatos, CA 95030, USA; marino@bonafurtuna.com \\ 5 Regional Department of Agriculture, Sicilian Region, 90145 Palermo, Italy; pippo.ricciardo@regione.sicilia.it \\ * Correspondence: claudia.speciale@ulpgc.es
}

check for

updates

Citation: Schicchi, R.; Speciale, C.; Amato, F.; Bazan, G.; Di Noto, G.;

Marino, P.; Ricciardo, P.; Geraci, A.

The Monumental Olive Trees as

Biocultural Heritage of

Mediterranean Landscapes: The Case Study of Sicily. Sustainability 2021, 13, 6767. https://doi.org/10.3390/

su13126767

Academic Editor: Pietro Santamaria

Received: 18 May 2021

Accepted: 11 June 2021

Published: 15 June 2021

Publisher's Note: MDPI stays neutral with regard to jurisdictional claims in published maps and institutional affiliations.

Copyright: (c) 2021 by the authors. Licensee MDPI, Basel, Switzerland. This article is an open access article distributed under the terms and conditions of the Creative Commons Attribution (CC BY) license (https:/ / creativecommons.org/licenses/by/ $4.0 /)$.

\begin{abstract}
Monumental olive trees, with their longevity and their remarkable size, represent an important information source for the comprehension of the territory where they grow and the human societies that have kept them through time. Across the centuries, olive trees are the only cultivated plants that tell the story of Mediterranean landscapes. The same as stone monuments, these green monuments represent a real Mediterranean natural and cultural heritage. The aim of this paper is to discuss the value of monumental trees as "biocultural heritage" elements and the role they play in the interpretation of the historical stratification of the landscape. We present the results of a survey of the most significant olive trees growing in Sicily. The selection was based on the "monumentality" aspects of trees, taking into account dendrometric parameters and environmental contexts. The collected dataset constitutes a heterogeneous sample of 367 specimens of considerable size that, in some cases, reach a circumference of about $19 \mathrm{~m}$. Starting from the data presented here, the whole Sicilian territory shows a historical relationship between human and olive. The presence of these plant monuments is, therefore, evidence of long-term, often centennial, landscapes as a result of sustainable use of the territory.
\end{abstract}

Keywords: agrobiodiversity; ancient trees; biocultural diversity; biodiversity; heritage trees; historical ecology; long-lived trees; Olea europaea; veteran trees

\section{Introduction}

The olive tree can be considered the most symbolic tree of civilization and a part of the anthropized Mediterranean landscape [1]. Exploited at least since the Mesolithic [2] and cultivated for the production of oil at least since the Bronze Age in Sicily [3,4], it has a wide distribution in all countries bordering the Mediterranean, with around 800 million individuals [5,6]. Evidence of mythology, history, and literature attest to the great importance of the olive tree and its oil in the trade, food, and customs of Mediterranean populations, starting with the olive tree as the protector tree of the city just founded by Athena and mentioned among the most precious trees by numerous Jewish, Greek, and Roman sources [6]. It is a very long-lived plant, with very slow growth, able to bear fruit for several hundreds of years, assuming extraordinary shapes and sizes over time and contributing to modern genetic diversity [7].

The use of the wild olive dates back to the Israeli region in the Epipaleolithic [4]. It is probably from primitive cultivation located in the west of Iran and the south of the Caucasus that the irradiation to other geographical areas and the differentiation of the 
different cultivated varieties began [5]. It is believed that the cultivated olive tree (Olea europaea L. var. europaea) is derived from the refinement of the wild one (Olea europaea var. sylvestris (Mill.) Lehr), which is spontaneous throughout the Mediterranean basin [8] and with which it retains considerable genetic affinities [9], although its origin is still much debated [10]; however, it is no coincidence that the aspect of the abandoned olive tree tends to regress toward that of the wild olive tree [11]. The distribution of the olive tree, in fact, is almost superimposed on that of its wild ancestor, representing one of the characteristic elements of Mediterranean sclerophyllous vegetation [8]. According to Zohary and Hopf [9], within the Mediterranean countries, the olive tree was one of the first fruit plants to be domesticated, perhaps as early as the 5th millennium BC, as evidenced by the several structures for the pressing of olives found in the Chalcolithic age in the Jordanian area [12].

The olive varieties we know today would therefore be the result of an ancient selection process [13] by Syrian and Palestinian farmers and probably also those from the vast area extending from the Southern Caucasus to the Iranian highlands, starting from the wild olive tree, widespread in that time period but not very usable for food purposes due to the spinescence and small drupes and their being poor in oil, to cultivars rich in oil and without thorns [14-16].

The relation between humans and olive trees in Sicily has a long story. Beyond the previously cited remains from Grotta dell'Uzzo, olive tree wood has been exploited in Eastern Sicily since the end of the Paleolithic [16]. According to the natural sequence of Pergusa lake, Olea sp. experienced an expansion starting from 7200 BP (Middle Neolithic) [17], but it is unlikely that it was due to its early cultivation. Archaeobotanical data confirm that olive tree wood and probably its fruits were used during the Bronze Age, 2nd millennium BC, despite missing carpological data [18-20]. For the Greek colonies such as Selinunte (7th century BC), the olive tree was considered a symbol of peace, wisdom, and prosperity for the various uses to which the oil was intended. Carpological data are scarce, probably due to the extremely low record of archaeobotanical remains for these phases; the only exception is the city of Camarina [21]. According to literary sources, the farmers of Selinunte became a point of reference in the oil trade in the Mediterranean. They cultivated and propagated the olive tree in the valleys and in the fertile lands of the hinterland, producing oil, as evidenced by the findings of rudimentary mills dating back to the fifth century BC [22] and exporting it, as the city of Akragas, to the Phoenicians colonies of Northern Africa [23].

It is evident that this tree constituted a preponderant and highly characterizing element of the ancient Sicilian agricultural landscape, also according to the literary sources. Thucydides (Book VII, 81, 4), speaking of a village south of Syracuse, called the Polizelo enclosure, where the Athenians stopped briefly in retreat, gives us the opportunity to imagine the olive fields delimited in "enclosures" by low walls of dry stones, as they are still today for the needs of sheep farming. One significant document with some valuable information on the olive tree in antiquity is the Tabulae Halaesinae, a Hellenistic description carved on two stone tablets of the land of Halaesa, an ancient city near the modern village of Tusa (Messina). Ancient olive trees are raised to the role of natural monuments through the marking of the Halaesian monogram engraved on the bark as a marking boundary sign [24]. In the Tabulae, the importance and predominance of olive cultivation for the economy of that territory come out, also supported by the presence of special "nurseries" (elaiokomion) [25]. During the Roman Empire, the exploitation of Sicilian oil together with other food resources was slowly replaced with the use of the island as a bridge for the import of Northern African products [26]. Finally, during the Middle Ages, its presence in the hilly Sicilian landscape seems quite spread, with some exceptions, especially in the Islamic areas [27-29].

Today the olive tree, together with wheat and vines, represent the "Mediterranean triad" of traditional agriculture [30]. In the Sicilian agricultural landscape, dry (non- 
irrigated) olive groves are widespread in pure plantations, with more or less irregular spacing, or in "mixed cultivation" systems, together with carob and almond trees.

The centuries-old olive trees and, more generally, all monumental trees, with their longevity and considerable size, certainly represent a sign that is not negligible for the purposes of a better understanding of the territory that hosts them and of the society that wanted them to be preserved. The attention to monumental olive trees is linked to the most up-to-date concepts of "istorical ecology" for the interpretation of the traditional rural landscape, in which the historical-anthropological components are intimately connected to the natural ones. As a matter of fact, as cultivated plants, olive trees are anthropogenic elements of the landscape, and, thanks to their longevity, they have become a source of historical information on the use of the territory. They are the only cultivated plants that tell the story of the Mediterranean landscapes through the Anthropocene and represent a "cultural heritage", like some stone monuments. Having evolved over the centuries, the olive tree landscapes represent a tangible example of sustainable land use [31]. The recognition of ancient and notable trees and historic orchards as elements of cultural heritage is widely accepted (see, e.g., www.english-heritage.org.uk), although, as they are living monuments, we believe it is more appropriate to consider trees as elements of the "biocultural heritage" [32].

While some research has focused on the role of olive groves in the Mediterranean landscape e.g., [33-35], less emphasis has been placed on the cultural/biocultural value of single monumental olive trees that dot the landscape.

Considering the importance of secular olive trees not only from a cultural, environmental, and scientific point of view, as well as for the precious genetic heritage of which they are depositories, in 2003, a survey project was started in Sicily in order to acquire significant elements for the documentation, protection, and enhancement of this plant heritage [36,37].

This work reports the results of the survey of monumental olive trees conducted in Sicily and discusses their value in terms of "biocultural heritage" and the importance they play in the interpretation of the historical stratifications of the landscape.

\section{Materials and Methods}

\subsection{Study Area}

Sicily is the largest Mediterranean island, with an area of approximately $25,500 \mathrm{~km}^{2}$ and about $1000 \mathrm{~km}$ of coastline. The island has different geological characteristics, which have shaped different landforms with an elevation ranging from sea level to $3340 \mathrm{~m}$ (Mount Etna). The territory is hilly in the central and southwestern parts (approximately $61.4 \%$ ), mountainous, especially in the northern and eastern parts (24.5\%), and $14.1 \%$ consists of alluvial plains [38].

According to Bazan et al. [39], Sicily is divided into 25 bioclimatic belts (thermotypes and ombrotypes) from thermomediterranean semiarid to cryo-mediterranean hyperhumid. This great variety of environmental conditions and its complex paleo-geographic and human history make the island one of the Mediterranean biodiversity hotspots.

Agricultural systems are widespread and are structured as highly diversified landscape mosaics (arable lands and extensive herbaceous crops, vineyards, olive groves and dry cultivation mosaics, orchards, built-up areas, etc.), which are significant containers of agrobiodiversity.

Olive groves create diffused semi-open landscapes compared to other tree crops, especially along the marginal hilly areas and at the base of the mountainous areas [40]. The cultivation of the olive tree currently has about 18 million plants in Sicily and contributes considerably to the characterization of the physiognomy of the region's agroecosystems, with particular reference to the hilly ones, where $65 \%$ of the olive groves exist, and to the mountain ones, where the traditional olive groves represent $17 \%$ of all groves [41]. With an area of 157,891 ha [42], equal to $6.1 \%$ of the regional territory, this cultivation plays an important role. 


\subsection{Data Collection}

The survey covered the entire Sicilian regional territory and the selection of the most significant specimens, chosen for their "monumentality" aspect, mainly took into account the parameters inherent to the measurement of maximum circumference, measured at $1.30 \mathrm{~m}$ from the ground (for appropriate comparisons with other individuals), height, development, crown width, and presumed age. This information was also integrated by considerations relating to the historical, naturalistic, and landscape value of the individual plants.

For the survey, the research group also made use of the collaboration of the technicians of the Operational Sections of Technical Assistance (SOAT) of the Regional Department of Agriculture, Rural Development, and Mediterranean Fisheries, located in the territory, which helped to report to the authors the presence of individuals with the characteristics of monumentality.

The research methodology was chosen in order to maintain the methodological continuity with previous surveys on monumental trees carried out in Sicily $[25,36,42,43]$. For the survey of monumental individuals, the survey form proposed by Schicchi and Raimondo [25] was used; it is made up of various items, listed below and contextually explained to summarize the methodology used for the acquisition of the information data:

1. Identification refers to the scientific binomial (or trinomial) of the taxon to which it belongs, to the vulgar name, to the local name, and to the family of reference;

2. Location, with reference to the surveyed sample, indicates the municipal area, the province, the IGM Italian Map Sheet, at scale 1:50,000, and the section of the Regional Technical Map at scale 1:10,000. This item also shows the geographical coordinates in UTM WGS84 format, information about the ownership of the area in which the monumental tree stands as well as the path to access it. The geographic coordinates, latitude and longitude, were identified by GPS (global positioning system). Mapping and spatial analysis were carried out using ESRI ArcGIS 10.2;

3. Stational parameters show the altitude expressed in meters above sea level ( $\mathrm{m}$ asl), the exposure, the position, the nature of the substrate, the vegetation context of which the surveyed tree is a part, and any existing protection measures, with particular reference to the Regional Parks and Regional reserves;

4. Main morphological features concern the structure and habit of growth, the circumference of the stem measured at $1.30 \mathrm{~m}$ from the ground, the maximum circumference of the trunk, the width (length and width) of the foliage, the height of the plant, and the presumed age. The circumference was measured, using a measuring wheel, at the point of maximum development, generally coinciding with the basal part of the stem or with the part below the insertion of the branches, and at a predetermined height (1.30 $\mathrm{m}$ from the ground) for appropriate comparisons between individuals belonging to the same species. In the case of plants located in areas subject to steep slopes, the measurement at $1.30 \mathrm{~m}$ from the ground was carried out in an intermediate position, between the upper and the lower part of the trunk, following not the line parallel to the ground but the one perpendicular to the trunk. The width of the canopy was measured differently: in the case of foliage with a basically circular base, the diameter of the projection on the ground was measured; in the case of irregular foliage, the greater length and width of their projection on the ground was measured. The height was measured using a hypsometer, a laser distance meter, metric rods, etc. The age estimation represents the closest approximation, as it is very difficult to determine. In fact, in centuries-old olive trees, the trunks are hollow and do not allow the use of classical methods of dendrochronology. Therefore, an age range was derived from an "expert-based" estimation [25] based on the growth rate of $1.5 \mathrm{~mm} /$ year by Michelakis [45]. This methodology, compared to the growth rates proposed by Arnan et al. [46] and Camarero et al. [47], is more suitable for the comparison with the growth measure carried out 25 years after some sampled trees. Age estimation was made at the root collar because many trees are branched at a height of less than $1.30 \mathrm{~m}$. 
In the attribution of age, both the growth features of the species and the fertility conditions of the site where the monumental olive trees were found were considered.

5. The condition of the specimen concerns the vegetative and health state (pathologies in progress, organs affected, the type of damage, the extent of damage, etc.), threats to its conservation, and any proposed conservation interventions. The vegetative and phytosanitary state is synthetically expressed on the basis of evaluations referring to a qualitative scale of the appreciated condition (excellent, good, fair, mediocre, and poor);

6. Notes and distinctive traits are reserved for all other possible information regarding the tree and/or the station in which it stands, including historical references, legends, etc.

\section{Results}

The collected dataset represents a heterogeneous sample for dendrometric parameters and environmental contexts. There are 367 specimens, 364 of which are Olea europaea var. europaea and 3 of which are Olea europaea var. sylvestris, of considerable size found in different Sicilian provinces (Figure 1). Of these, a significant part is located in the provinces of Agrigento, Messina, Palermo, and Syracuse. The collected data were computerized to facilitate its management, consultation, and implementation over time. A significant example of the surveyed specimens, divided by regional province and referring to 50 individuals, is reported in Table 1. Of 367 specimens, 74 are part of the province of Agrigento, 73 are of Messina, 64 are of Palermo, 56 are of Syracuse, 30 are of Trapani, 21 are of Ragusa, 20 are of Catania, 16 are of Enna, and 13 are of Caltanissetta (Figure 2).

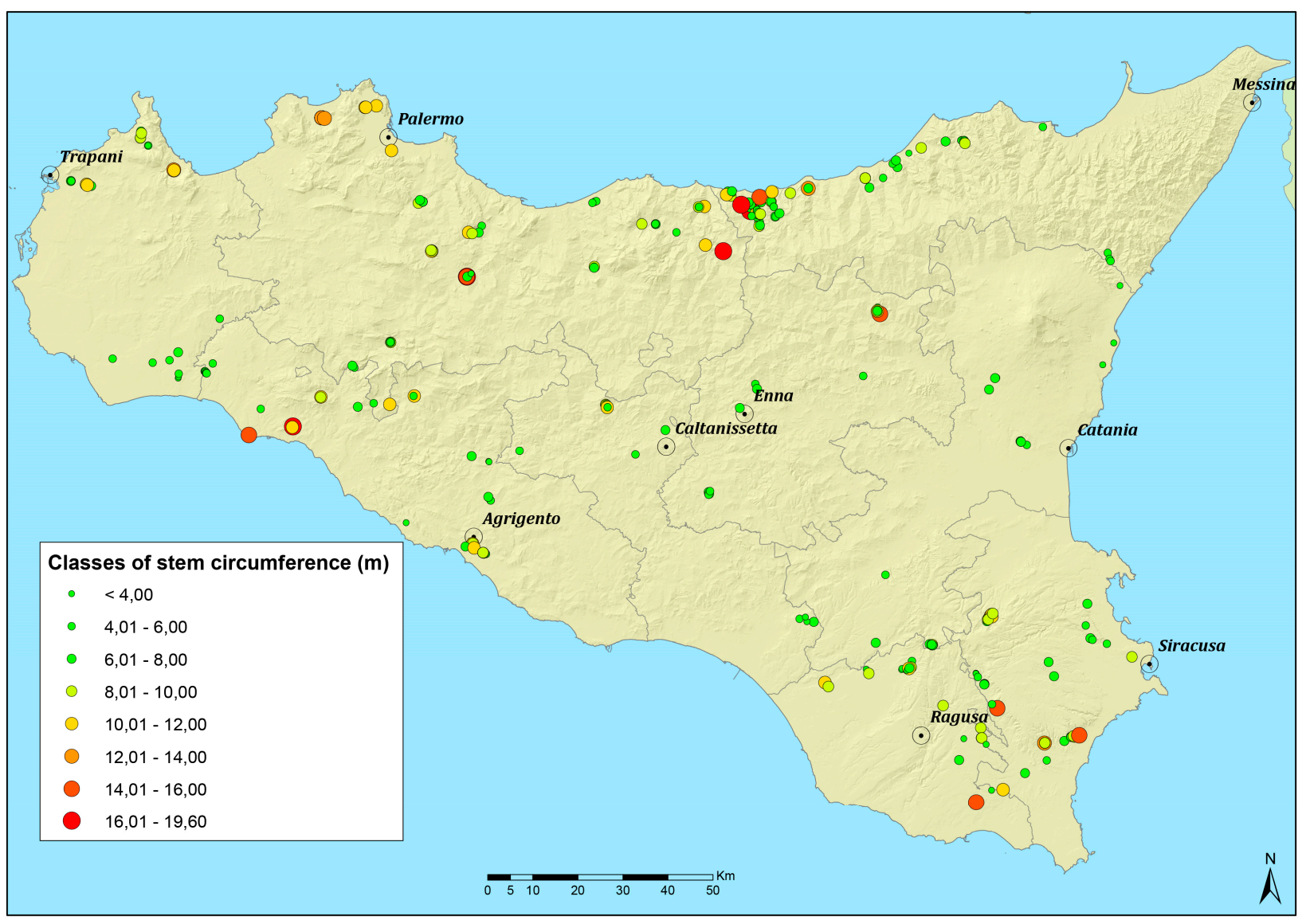

Figure 1. Distribution of 367 monumental olive trees of Sicily represented by classes of stem circumference (at root collar). 
Table 1. Sample of the 50 most significant monumental olive trees. The complete list of specimens is given in the supplementary materials.

\begin{tabular}{|c|c|c|c|c|}
\hline Name & Municipality & Province & Circ. & Age \\
\hline Olivo di Innari 1 & Pettineo & Messina & 19.60 & 2081 \\
\hline Olivo di Vallefonda 4 & Vicari & Palermo & 19.00 & 2017 \\
\hline Olivo di Calabrò & San Mauro Castelverde & Palermo & 18.00 & 1911 \\
\hline Olivo di Fontana Calda 1 & Sciacca & Agrigento & 17.00 & 1805 \\
\hline Olivo di contrada La Gebbia & Avola & Siracusa & 15.50 & 1645 \\
\hline Olivo di Feudo Vassallo & Sciacca & Agrigento & 15.20 & 1613 \\
\hline Olivo di Palazzelli & Modica & Ragusa & 15.10 & 1603 \\
\hline Olivo di Fraginesi 1 & Castellammare del Golfo & Trapani & 13.00 & 1380 \\
\hline Olivo di Predica 1 & Caronia & Messina & 12.90 & 1369 \\
\hline Olivo della Contemplazione & Carini & Palermo & 12.70 & 1348 \\
\hline Olivo di Busulmone & Noto & Siracusa & 12.60 & 1337 \\
\hline Olivo secolare di Troina1 & Troina & Enna & 12.10 & 1284 \\
\hline Olivo di Cattiva 4 & Alessandria della Rocca & Agrigento & 11.40 & 1210 \\
\hline Olivo secolare di Mokarta 2 & Erice & Trapani & 11.30 & 1199 \\
\hline Il Patriarca della Favorita & Palermo & Palermo & 11.10 & 1178 \\
\hline Olivo del Cinghiale & Agrigento & Agrigento & 11.00 & 1168 \\
\hline Olivo di Maviti & Pettineo & Messina & 10.80 & 1146 \\
\hline Olivo di Fontana calda 2 & Sciacca & Agrigento & 10.50 & 1115 \\
\hline Olivo di Muti 4 & Chiaramonte Gulfi & Ragusa & 10.50 & 1115 \\
\hline Olivo di Scorsone 3 & Ispica & Ragusa & 10.50 & 1115 \\
\hline Olivo di Lippia & Acate & Ragusa & 10.30 & 1093 \\
\hline Olivo di Pullicia di Sopra & Palazzo Adriano & Palermo & 10.10 & 1072 \\
\hline Olivo di Verdesca 1 & San Vito Lo Capo & Trapani & 10.00 & 1062 \\
\hline Olivo di Zocco-Vernera 4 & Buccheri & Siracusa & 9.70 & 1030 \\
\hline Olivo di Castelluzzo 2 & San Vito Lo Capo & Trapani & 9.50 & 1008 \\
\hline Olivo di Misilmeri & Misilmeri & Palermo & 9.50 & 1008 \\
\hline Olivo di Centunzi & Caltavuturo & Palermo & 9.10 & 966 \\
\hline Olivo Grande di Bonamorone & Agrigento & Agrigento & 9.10 & 966 \\
\hline Olivi di Acquedolci & Acquedolci & Messina & 9.00 & 955 \\
\hline Olivo di Sacramento 3 & Buccheri & Siracusa & 8.50 & 902 \\
\hline Olivo di Santa Tecla & Capri Leone & Messina & 8.20 & 870 \\
\hline Olivo di via dell'olivo Millenario 1 & Motta Sant'Anastasia & Catania & 8.00 & 849 \\
\hline Olivo di Nicoletta & Enna & Enna & 7.80 & 828 \\
\hline Olivo di via dell'olivo Millenario 5 & Motta Sant'Anastasia & Catania & 7.60 & 807 \\
\hline Olivo di Milo 2 & Trapani & Trapani & 7.50 & 796 \\
\hline Olivo di Piraino & Licodia Eubea & Catania & 7.50 & 796 \\
\hline Olivo di S. Maria di Licodia & Santa Maria di Licodia & Catania & 7.50 & 796 \\
\hline Olivo di Fontecà & Pettineo & Messina & 7.40 & 786 \\
\hline Olivo di Sugherazzo & San Fratello & Messina & 7.40 & 786 \\
\hline Olivo di Tardara & Tusa & Messina & 7.40 & 786 \\
\hline Olivo di Contonaro-Lavanche 1 & Caltabellotta & Agrigento & 7.20 & 764 \\
\hline Olivo di Vituso 2 & Niscemi & Caltanissetta & 7.20 & 764 \\
\hline Olivo di Falabia 3 & Palazzolo Acreide & Siracusa & 6.90 & 732 \\
\hline Olivo di Contonaro-Lavanche 2 & Caltabellotta & Agrigento & 6.80 & 722 \\
\hline Olivo di Rastello & Pietraperzia & Enna & 6.70 & 711 \\
\hline Olivo di Monaci & Caccamo & Palermo & 6.50 & 690 \\
\hline Olivo di Seggio & Castelvetrano & Trapani & 6.40 & 679 \\
\hline Olivo di Garofalo & Canicattini Bagni & Siracusa & 6.30 & 669 \\
\hline Olivo della Madonna del Piano & Grammichele & Catania & 6.00 & 637 \\
\hline Oleastro di Inveges & Sciacca & Agrigento & 5.20 & 552 \\
\hline
\end{tabular}

With reference to the maximum circumference value of the stem (measured at the collar), $11.4 \%$ of them have circumference values equal to or less than $4 \mathrm{~m} ; 30.5 \%$ have values between 4 and $6 \mathrm{~m} ; 31.3 \%$ have values between 6 and $8 \mathrm{~m} ; 14.2 \%$ have values between 8 and $10 \mathrm{~m} ; 7.1 \%$ have values between 10 and $12 \mathrm{~m} ; 2.7 \%$ have values between 12 and $15 \mathrm{~m} ; 2,7 \%$ have values greater than $15 \mathrm{~m}$. 
Considering the age of the surveyed plants, $7.1 \%$ of them are between 200 and 400 years old, $26.4 \%$ are between 400 and 600 years, 33.5\% are between 600 and 800 years, $15.3 \%$ are between 800 and 1000 years, and $17.7 \%$ over 1000 years.

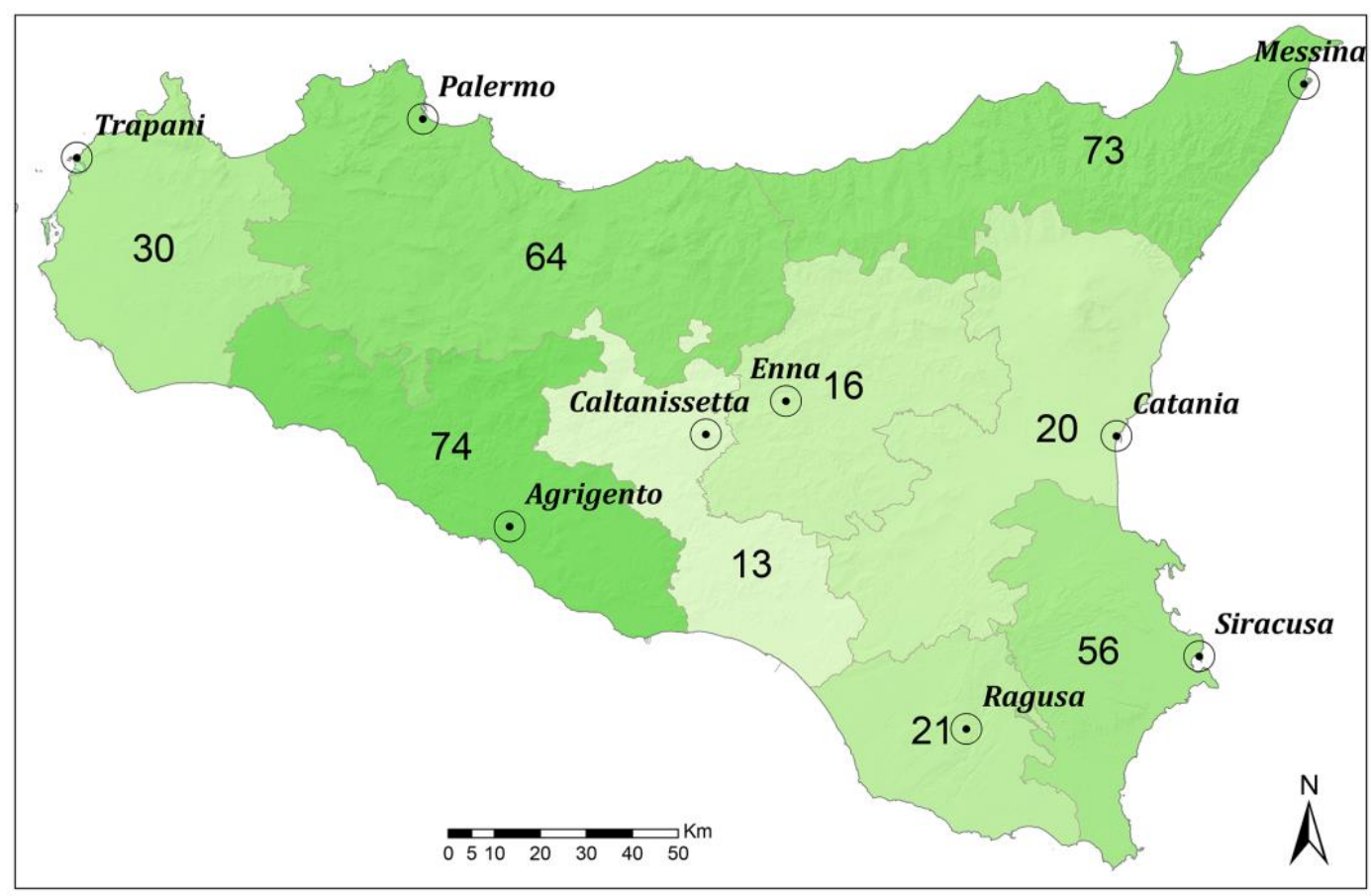

Figure 2. Distribution of monumental olive trees in the Sicilian provinces.

In particular, examining the data relating to the aforementioned sample, it is possible to argue that, in the province of Agrigento, there are several extraordinary olive trees among which, in addition to the very suggestive ones of the Greek Valley of the Temples, there are some plants of about 800-1100 years present in the municipalities of Agrigento (Figure 3a), Caltabellotta (Figure 3b), and Sciacca, with circumference values ranging from 6 to $17 \mathrm{~m}$. Additionally noteworthy is the Olivastro di Inveges, located in the Sciacca area, full of history and legends, with a stem of about $5 \mathrm{~m}$ in circumference.

In the province of Caltanissetta, the largest olive trees are found mainly in the territory of the chief town, in the Canalotto-Mimiani, Vituso, and Bugini districts. These are ancient specimens with maximum circumference values between 5 and 11.40.

In the province of Catania, among the most beautiful monumental olive trees, there are specimens along the millenary olive tree road, in the municipal area of Motta S. Anastasia, with specimens up to $8 \mathrm{~m}$, while in the province of Enna, there are ancient specimens with a maximum circumference between 3.40 and $14.1 \mathrm{~m}$.

Among the most noteworthy olive trees in the province of Messina, aged between 414 and 2081 years, we can mention those present in the Nebrodi mountains territory, with particular reference to the area between Tusa, Pettineo, Acquedolci, and Caronia. In particular, the Predica area of the latter municipality contains one of the most relevant examples (Figure 3d). It has a maximum circumference of $12.9 \mathrm{~m}$ at the stump and a monocormic stem of $9.30 \mathrm{~m}$ at breast height, with various ribs with rounded edges, cavities, and grooves that, from the insertion of the crown, reach the ground. This specimen, over 1360 years old, can most likely be considered one of the largest olive trees in Sicily and Italy.

Among the numerous other notable specimens for age, shape, and size, we remember those of the Maviti and Innari areas in the territory of Pettineo (Messina): the first (Figure 3c) consists of a large stump of about $10.8 \mathrm{~m}$ in circumference, surmounted by two trunks of particular beauty, for shape and bearing, of 6.30 and $4.50 \mathrm{~m}$ in circumference to breast 
height; the second has a large stump of $19.60 \mathrm{~m}$ in circumference surmounted by three trunks with a breast height circumference of $4.60,2.90$, and $2.40 \mathrm{~m}$, respectively.
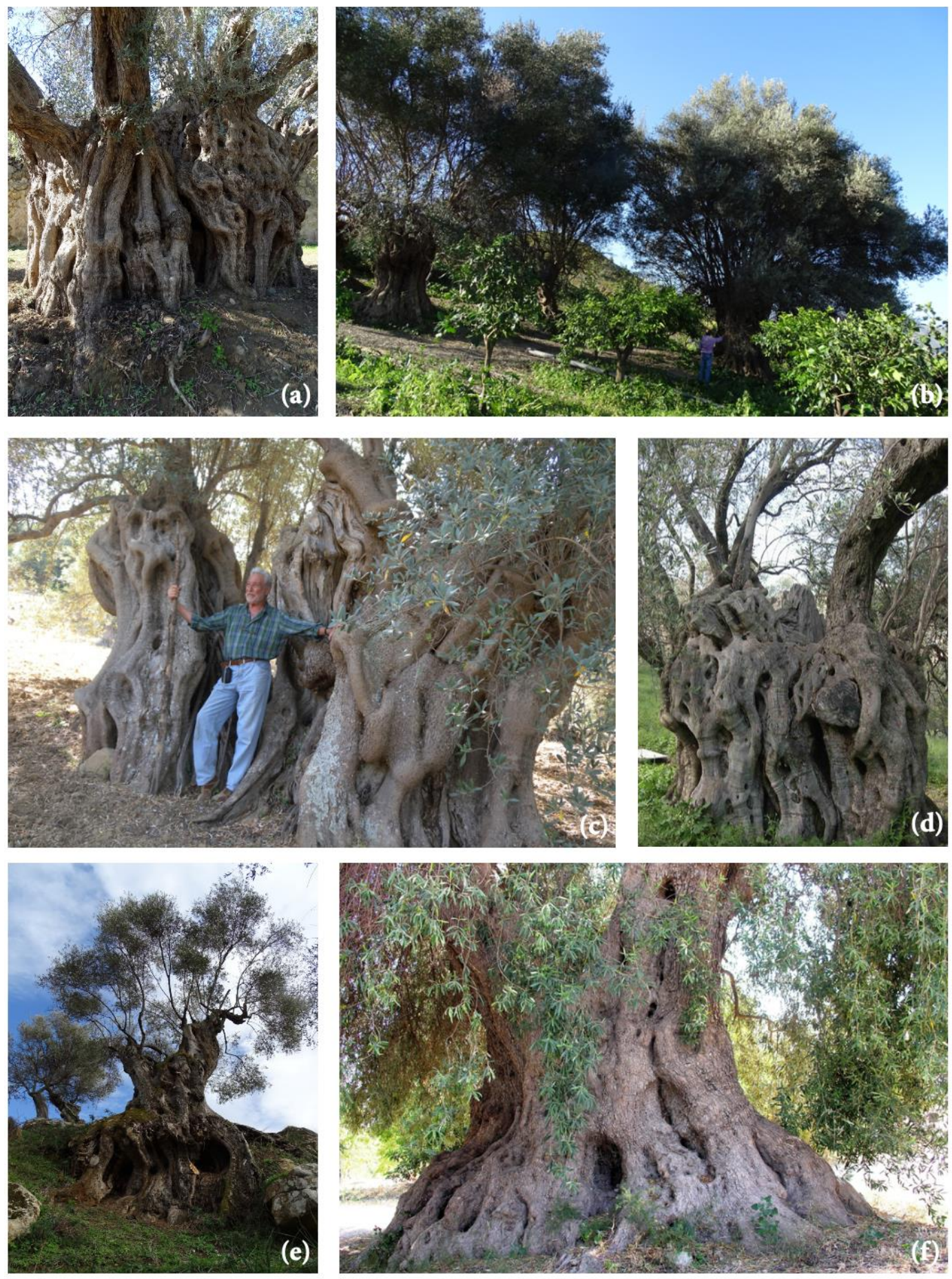

Figure 3. Some of the monumental olive trees of Sicily: (a) Olivo grande di Bonamorone (Agrigento); (b) Olivi di Caltabellotta; (c) Olivo di Contrada Maviti (Pettineo); (d) Olivo di Predica (Caronia); (e) Olivo di Calabrò (San Mauro Castelverde); and (f) Olivo di Busulmone (Noto).

Several olive trees in the province of Ragusa, distributed in the municipalities of Chiaramonte Gulfi, Acate, Modica, and Ispica, are striking for their bizarre shapes and sizes. In the territory of the latter municipality, there is an extraordinary olive tree of Scorsone of about 1115 years, with a maximum circumference of $10.5 \mathrm{~m}$ at the collar. 
In the territory of Siracusa, extraordinary olive trees can be found in Buccheri, Noto, and Avola. The most representative are certainly those of the Busulmone district (Noto), which, with a circumference of $12.60 \mathrm{~m}$ at the level of the stump and $7.20 \mathrm{~m}$ at breast height, are probably 1338 years old (Figure 3f), and those of the area La Gebbia (Avola) with a circumference of $15.50 \mathrm{~m}$ at the collar and $10.10 \mathrm{~m}$ at breast height.

In the territory of the province of Palermo, considerable olive trees are found in the municipalities of Caltavuturo, Carini, Misilmeri, Palermo, Pollina, San Mauro Castelverde (Figure 3e), and Vicari, where several individuals with very large stumps show maximum circumference values of up to $19 \mathrm{~m}$.

In the province of Trapani, worthy of consideration are several ancient olive trees present in the municipalities of San Vito Lo Capo, Castellammare del Golfo, Castelvetrano, and Trapani, which have maximum circumference values between 3.5 and $12 \mathrm{~m}$.

The secular olives are located at an altitude ranging from 24 to $841 \mathrm{~m}$ asl, showing a distribution with an average value of $304 \mathrm{~m}$ and a standard deviation of $175 \mathrm{~m}$. The distribution of olive trees across soil types shows no significant effect of substrata, indicating the plasticity of the species. A total of 267 specimens grow on basic lithotypes (limestone, dolomite, marl, gypsum, and calcarenite), and 94 grow on acid lithotypes (vulcanite, flysch, and quartzite).

Only four trees fall within the regional natural reserves, eight are located in Madonie Natural Park, and five are in Nebrodi Natural Park.

Concerning the structure and habit of growth, the tree crown diameter varies from 7 to $15 \mathrm{~m}$ and, in the case of irregular shape, ranges from 5 to $13 \mathrm{~m}$ in the N-S direction and from 4 to $15 \mathrm{~m}$ in the $\mathrm{E}-\mathrm{W}$ direction. The height of the surveyed plants changes between 5 and $15 \mathrm{~m}$, in relation to the different techniques of pruning or in relation to the state of cultural abandonment or in order to maintain the foliage at a level that allows the grazing of livestock without damaging plant production.

Vegetative and health conditions are excellent in $4.9 \%$ of specimens, good in $24.8 \%$, fair in $53.7 \%$, mediocre in $14.4 \%$, and poor in $2.2 \%$.

\section{Discussion}

The olive tree is a rustic species able to live on different types of soil. Over the centuries, it has been widely spread in all of the provinces of Sicily, from sea level to wherever the climatic conditions have allowed it (about $900 \mathrm{~m}$ asl). It has become, over time, the tree that dominates and is one of the most expressive, if not the most expressive, tree of the Sicilian agricultural landscapes, together with the marginally determined manna ash (Fraxinus angustifolia Vahl), another species of the same family [48,49].

Traditional olive groves with monumental specimens host a high number of varieties. The importance of this latter genetic resource and the potential it holds for agriculture is also a common element in other European and Mediterranean contexts, as shown by the recent studies on centenary olive trees conducted in several Mediterranean countries [50-55]. The cataloging, characterization, and in situ conservation of secular olive trees is, in fact, a priority to safeguard their genetic, natural, and agricultural value and to protect ancient genotypes threatened with extinction [56,57].

The varietal diversity of olive germplasm in Sicily is represented by 25 cultivars with different features in terms of the morphology, production, and quality of the oil [58].

The surveyed monumental olive trees belong to 11 different cultivars, including the cv. Fastucara, Biancolilla, and Cerasuola in the province of Agrigento, the cv. Ogliarola Messinese in Caltanissetta, the cv. Santagatese and Nocellara Etnea in Catania, and mainly the cv. Moresca in Enna.

In the province of Messina, the monumental specimens mainly belong to the Santagatese cultivar and, to a lesser extent, to the Ogliarola Messinese. In the province of Palermo, in addition to cv. Ogliarola Messinese and Santagatese, there are also some individuals belonging to the cv. Nerba. In Southern Sicily, monumental olive trees are of cv. Tonda Iblea and Moresca in the province of Ragusa and cv. Virdisa or Pizzuta in the 
Syracuse area. In the western sector of the island, in the province of Trapani, in addition to the Nocellara del Belice, there are olive trees of cv. Cerasuola, Santagatese, and Tonda Iblea.

These are ancient cultivars grafted onto the wild olive trees that have given rise to irregularly planted olive groves, favoring the natural lay of the soil; several centuries-old plants still survive, cultivated extensively, with generally hollow trunks or with numerous cavities, which constitute microhabitats for vertebrate and invertebrate fauna. To preserve these trees in the best vegetative condition, as far as possible, it is necessary to ensure adequate crop care, including rational pruning, aimed at removing dying branches and aerating the foliage, monitoring and fighting against the agents of wood decay, and contrast, in some cases, to attacks by harmful insects and fungi. For some specimens, located in the Nebrodi mountains, it is also necessary to proceed with the removal of Viscum album L. and Loranthus europaeus Jacq., two semi-parasitic species that often develop abundantly on the canopy of centuries-old olive trees causing a vegetative decay and subsequently a worsening of the phytosanitary conditions

However, Olea europaea is a species characterized by remarkable longevity and by an extraordinary resistance to drought, due to different forms of anatomical and physiological adaptation, so much that it can survive and provide a certain fruit production even in conditions of low rainfall. It also resists fires very well due to its remarkable ability to emit vigorous suckers from the buds present on the stump after the passage of the fire. Therefore, the olive tree can be defined, with good reason, as "a plant that never dies". In this regard, Morettini [59] assigns the qualification of perennial species to the olive tree, observing that "the aerial portion is not perennial [, but] the underground portion it is; it is the base which, expanding into the bases formed by the new trunks that have succeeded over the centuries, replacing [ ... ] the oldest ones, retains the vitality and a set of generations of other younger olive trees".

The antiquity of olive growing in the Sicilian territory is testified by several archaeological and historical finds, artifacts, laws, deeds, and inventories, as well as by the numerous toponyms of various places that recall the olive tree (Ogliastro, Marcatagliastro, Alivazza, Ogliastrillo, Madonna dell'Olio, etc.) and, above all, from the discovery of ancient plants and/or stumps. The oldest olive trees found in the Sicilian territory are spread within the areas where the wild variety of the olive tree lives or can potentially live. The latter is an important element of the Mediterranean scrub of which it constitutes particularly expressive formations, settled on the semi-rupestrian stations, both on calcareous and quartzarenitic soils, along the coasts and in the hinterland where the temperature almost never drops below $0{ }^{\circ} \mathrm{C}[11]$.

In Sicily, as it is in the rest of the Mediterranean, olive trees are relevant landscape elements because of their considerable economic, cultural, and environmental roles. According to Cancila [60], in the fourteenth century, the olive trees, with the exception of the provinces of Palermo and Catania, did not constitute wide groves; they were spread elements of a mixed agricultural system, very common in the island country. At the end of the fifteenth century, olive growing was also quite widespread in the province of Messina, and considerable development began in other areas of Sicily in the sixteenth century.

Currently, the island's olive trees are mainly grown in semi-intensive or traditional dry systems, both in specialized and mixed cultivation. The landscapes characterized by the olive tree are widespread and diversified in the regional territory in relation to the history of the places and the pedological and microclimatic characteristics and, above all, to the position, which also influenced the cultivation methods (Figure 4).

In hilly and coastal areas of Western and Southern Sicily, in favorable geopedological conditions, specialized olive groves are widespread and, until the mid-twentieth century, constituted a real cornerstone of the rural economy of the island. In addition to having considerable importance for production and a strong identity value for the landscape, the olive grove plays a fundamental role in protecting the soil, especially in areas with higher slopes where older plants are present. It is in these areas that most of the monumental olive trees surveyed in this work have been preserved. 


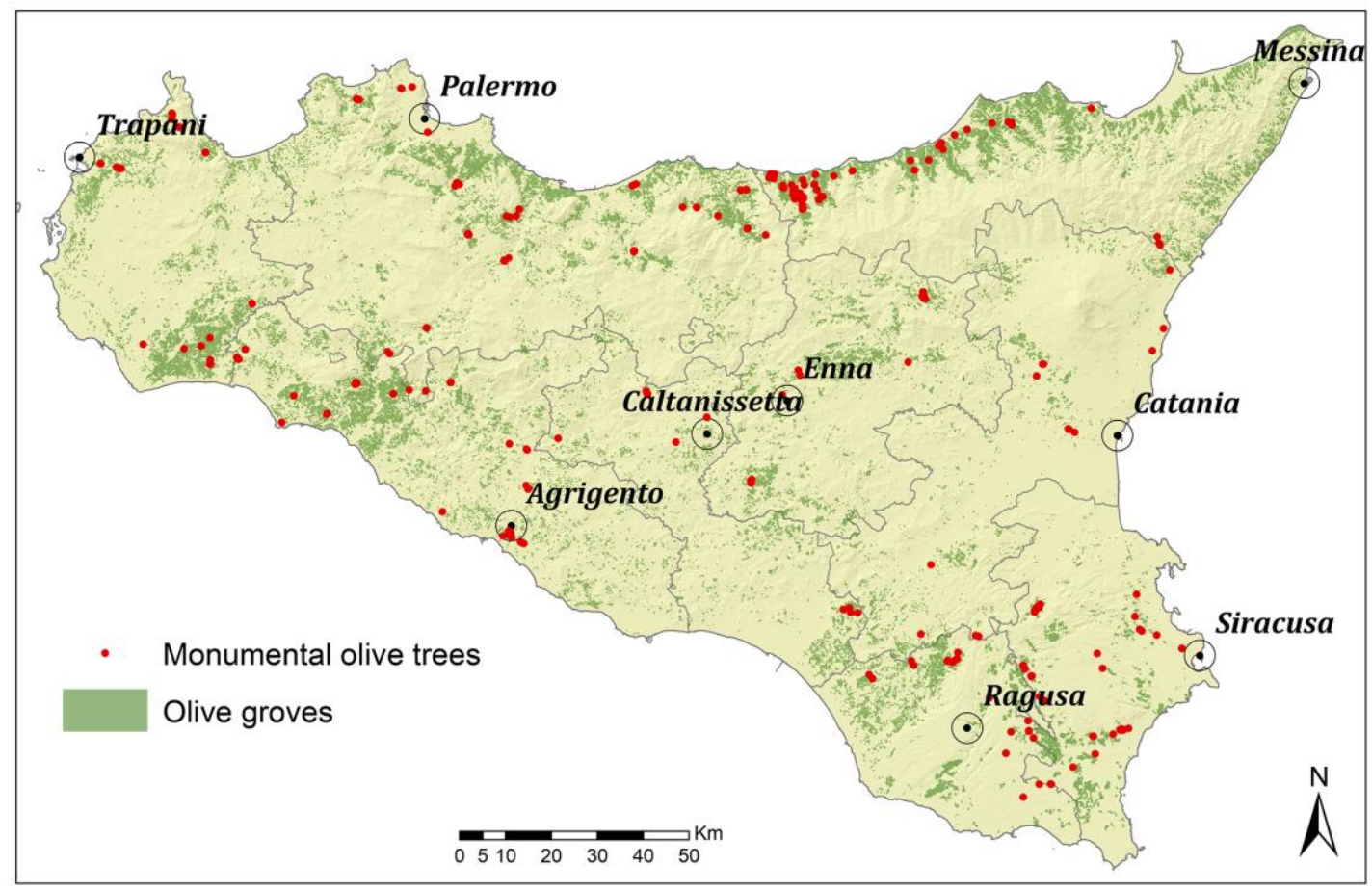

Figure 4. Distribution of the monumental olive trees in the olive Sicilian landscapes.

In coastal areas, especially in Southern and Eastern Sicily, the olive tree represents a characteristic element of mixed agricultural systems together with the carob, almond, and pistachio trees. These systems have been maintained in marginal areas, with often uneven morphologies, where the olive trees are unevenly distributed in the plots. In the traditional groves of the foothills, the individual trees are sometimes protected from erosion thanks to drystone lunettes. In other areas (e.g., in the Etna area), the olive tree can also be found within terraced polycultural systems.

Many olive groves in Northern Sicily, located in the province of Messina and Palermo, within the ancient marquisate of Geraci, date back to the early sixteenth century when the Marquis Ventimiglia allowed the farmers to graft the wild oleasters that grew spontaneously in his fields, letting them become owners of the single trees: this gave origin to a promiscuous property, as the land, where the inhabitants could exercise civic uses, remained in the hands of the feudal lord [60].

Cases of mixed ownership, although less frequent than in the past, are still known both on the Madonie mountains, especially in the territory of Castelbuono, and on the Nebrodi mountains, in the municipality of Tusa. A tangible sign of this anachronistic form of ownership is the engraving on the stem of the initial letter of the tree owner's surname (Figure 5), often highlighted in recent decades with a red painting [43]. The promiscuous property in Sicily concerns only the olive tree and no other cultivated tree species; as a matter of fact, because of its longevity, the olive tree is considered as real estate and therefore transmissible by inheritance.

Furthermore, on the northern side of the Madonie mountains, there is an extraordinary landscape created by the promiscuity of ancient olive trees within the relict manna ash tree grove. In this context, there is no lack of fruit species, such as pear, almond, fig, rowan, apricot, and plum.

In Eastern Sicily, on the slopes and on the Iblean plateau, olive trees spot the fields of wheat or pastures. The landscape of this arbored arable land is marked by an extensive system of fences built with dry stone walls. Inside these, there are ancient and isolated olive, almond, and carob trees, many of which are of extraordinary size and with limited productivity. In this context, the presence of several monumental olive trees is very frequent. 


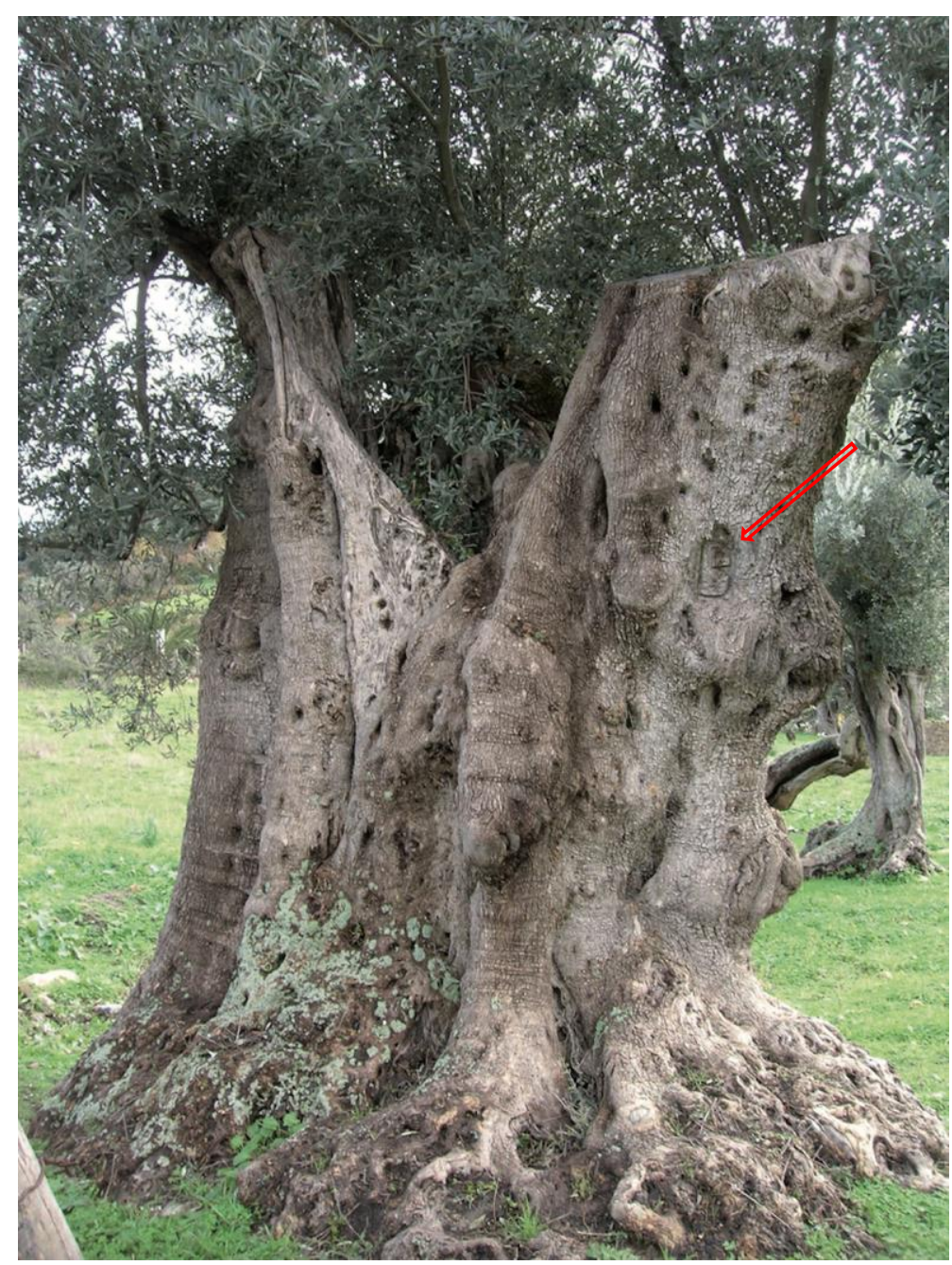

Figure 5. The Olivo di Zimmari (Tusa) engraved on the stem of the initial letter of the tree owner's surname is different from the landowner.

The traditional olive agroecosystems with monumental olive trees constitute peculiar tiles of the expressive Sicilian landscape consisting of a heterogeneous mosaic of agricultural systems and semi-natural systems, more or less fragmented and interspersed with hedges, dry stone walls, and narrow bands of forest species, which result in a high taxonomic and landscape diversity. The presence of monumental olive trees can be considered an indicator of the high biocultural diversity in the landscape and its agroecosystems. These last ones, given their diffusion in Sicily, define territorial mosaics with a high "widespread naturalness" [61], in which extensive agricultural practices are applied with a low environmental impact, compatible with the sustainable management of natural resources. They host rather diversified residual habitats, characterized by species of high conservation interest (e.g., [62-67]) and by a rich flora of ethnobotanical interest that is used for food purposes by local populations $[68,69]$ or for its dyeing properties [70]. Along the margins, there are frequent residues of the ancient Rhus coriaria L. cultivation, recently re-evaluated for the antioxidant properties of the fruits [71]. According to Blasi et al. [72], the olive grove is a cultivation that maintains a dynamic link with potential natural vegetation.

The recognition of the value of these landscapes in terms of biodiversity conservation has led Biondi et al. [73] to suggest their inclusion in Annex I of the EEC Directive 92/43, called "Centuries-old olive groves with evergreen Quercus spp. and arborescent mattoral" (code 6320), as a priority habitat, considering them peculiar to the Mediterranean region.

The olive tree, with its unmistakable persistent foliage, glaucous green on the upper page and silvery-gray on the lower page, gives itself and its landscape a particular and 
unusual beauty. In this context, numerous monumental specimens, with their particular shapes and extraordinary dimensions, testify to the slow passing of the centuries and the succession of human generations. For this reason, monumental olive trees can represent the destination or one of the major attractions of naturalistic itineraries within agroecosystems and the "oil routes". These green patriarchs, in fact, can alone constitute the reason for a trip, since they always have something special to offer: their shape, their size, and their age make each of them unique, and visitation of them is a memorable event [44].

From the data reported in this work, it emerges that, throughout the Sicilian territory, the relationship between man and the olive tree is historicized, as can be inferred both from the different signs of material culture, of which centuries-old olive trees constitute an extraordinary testimony and from the historical sources. Their longevity, the longest among cultivated plants, allows for a stratified reading of the contemporary landscape in which these "plant monuments" are the silent witnesses of the transformations of the environment that characterized the Anthropocene.

The monumental olive trees represent the bulwarks of a Mediterranean agricultural landscape that, over the last millennium, in many parts, has undergone limited alterations, at least up to about 60 years ago. In recent decades, this precious heritage, of incomparable historical, landscape, and scientific value, is seriously in danger of disappearing due to the abandonment of cultivation, especially in the hilly and foothills areas on sloping soils and by fires. Therefore, a renewed attention and protection toward these monuments of nature is crucial.

\section{Conclusions}

The Mediterranean agricultural landscape expressed by the olive tree has unique features, and it is still possible to find numerous monumental individuals in it, extraordinary for their age, shape, and size. They constitute authentic milestones both for the expressiveness they impress on the agricultural landscape, of which they are the significant elements and for the conservation of the precious germplasm of which they are custodians. The monumental olive trees represent, in fact, a reservoir of genetic diversity, which includes characteristics associated with resilience and adaptation to specific environmental conditions and which has allowed for resistance for several centuries, some for over a millennium, to the action of climatic agents, parasitic and anthropogenic activities, and the passage of fire. Therefore, they constitute the best guarantee for the future of olive growing, a sector of agricultural production that is fundamental for maintaining the Mediterranean identity, from an environmental, food, and social point of view.

The survey of secular olive trees, in addition to the considerable interest it holds in the context of the characterization and typification works of the olive-growing heritage, is also important from an eco-touristic point of view, being able to represent the destination or one of the major attractions of naturalistic itineraries within agroecosystems.

On the basis of the results of this paper, the following general recommendations should be taken into account for the conservation of monumental olive trees:

- Start long-term conservation projects beyond the horizon of European Community Policy, aimed at tangible results and more efficient use of financial resources. Monumental olive trees are biological entities depending on human care, and post-project abandonment would undermine the conservation effort;

- Establish a field collection of the germplasm of the Mediterranean monumental olive trees both for conservation purposes and with the aim of coping with climate change due to their extraordinary resilience;

- Promote on-farm germplasm conservation of monumental olive trees, which is an appropriate conservation strategy for this type of biodiversity that is strictly linked to the environmental and cultural contexts of origin;

- Recover and enhance traditional agricultural systems of olives. This approach preserves both agrodiversity and landscape, enhancing rural contexts' tourism attractiveness; 
- Recover traditional agricultural knowledge (TAK) in management of secular olive trees, so preserving the associated biocultural heritage;

- Acknowledge monumental olive trees as cultural heritage under UNESCO's normative framework.

Supplementary Materials: The following are available online at https://www.mdpi.com/article/10 $.3390 /$ su13126767/s1. Table S1: List of the 367 monumental olive trees sampled in Sicily.

Author Contributions: Conceptualization, R.S. and G.B.; methodology, R.S.; investigation, C.S., F.A., G.D.N., P.M., and P.R., data curation, R.S. and A.G.; GIS analysis and mapping, G.B; writing-review and editing, R.S., G.B., C.S., and A.G.; supervision, R.S.; funding acquisition, R.S. All authors have read and agreed to the published version of the manuscript.

Funding: Financial support was received from "Fondo di Finanziamento della Ricerca di Ateneo (FFR2019)".

Institutional Review Board Statement: Not applicable.

Informed Consent Statement: Not applicable.

Data Availability Statement: Not applicable.

Acknowledgments: The authors would like to thank the anonymous reviewers for their helpful readings and suggestions that improved the overall quality of the text.

Conflicts of Interest: The authors declare no conflict of interest.

Dedication: The authors wish to dedicate this article to the memory of Rolando Juan Carlos León, Professor of Ecology at the Faculty of Agronomy of the University of Buenos Aires, who loved Sicily and its biodiversity (Figure 3c).

\section{References}

1. Loumou, A.; Giourga, C. Olives Groves: The Life and Identity of the Mediterranean. Agri. Hum. Values 2003, 20, 87-95. [CrossRef]

2. Costantini, L. Foraging and Farming: The Evolution of Plant Exploitation; Harris, D.R., Hillman, G.C., Eds.; Unwin Hyman: London, UK, 1989.

3. Tanasi, D.; Greco, E.; Noor, R.E.; Feola, S.; Kumar, V.; Crispino, A.; Gelis, I. 1H NMR, 1H-1H 2D TOCSY and GC-MS analyses for the identification of olive oil in Early Bronze Age pottery from Castelluccio (Noto, Italy). Anal. Methods 2018, 10, $2756-2763$. [CrossRef]

4. Caracuta, V. Olive growing in Puglia (southeastern Italy): A review of the evidence from the Mesolithic to the Middle Ages. Veg. Hist. Archaeobotany 2020, 29, 595-620. [CrossRef]

5. Besnard, G.; Khadari, B.; Navascués, M.; Fernández-Mazuecos, M.; El Bakkali, A.; Arrigo, N.; Baali-Cherif, D.; de Caraffa, V.B.-B.; Santoni, S.; Vargas, P.; et al. The complex history of the olive tree: From Late Quaternary diversification of Mediterranean lineages to primary domestication in the northern Levant. Proc. R. Soc. B 2013, 280, 20122833. [CrossRef] [PubMed]

6. Kaniewski, D.; Van Campo, E.; Boiy, T.; Terral, J.-F.; Khadari, B.; Besnard, G. Primary domestication and early uses of the emblematic olive tree: Palaeobotanical, historical and molecular evidence from the Middle East. Biol. Rev. 2012, 87, 885-899. [CrossRef] [PubMed]

7. Chalak, L.; Haouane, H.; Essalouh, L.; Santoni, S.; Besnard, G.; Khadari, B. Extent of the genetic diversity in Lebanese olive (Olea europaea L.) trees: A mixture of an ancient germplasm with recently introduced varieties. Genet. Resour. Crop Evol. 2015, 62, 621-633. [CrossRef]

8. Gianguzzi, L.; Bazan, G. The Olea europaea L. var. sylvestris (Mill.) Lehr. forests in the Mediterranean area. Plant Sociol. 2019, 56, 3-34. [CrossRef]

9. Zohary, D.; Hopf, M. Domestication of Plants in the Old World: The Origin and Spread of Cultivated Plants in West Asia, Europe and the Nile Valley, 3rd ed.; Oxford University Press: Oxford, UK, 2000.

10. Valamoti, S.M.; Gkatzogia, E.; Ntinou, M. Did Greek colonisation bring olive growing to the north? An integrated archaeobotanical investigation of the spread of Olea europaea in Greece from the 7th to the 1st millennium bc. Veg. Hist. Archaeobotany 2017, 27, 177-195. [CrossRef]

11. Gianguzzi, L.; Bazan, G. A phytosociological analysis of the Olea europaea L. var. sylvestris (Mill.) Lehr. forests in Sicily. Plant Biosyst. Int. J. Deal. All Asp. Plant Biol. 2020, 154, 705-725. [CrossRef]

12. Dighton, A.; Fairbairn, A.; Bourke, S.; Faith, J.T.; Habgood, P. Bronze Age olive domestication in the north Jordan valley: New morphological evidence for regional complexity in early arboricultural practice from Pella in Jordan. Veg. Hist. Archaeobot. 2017, 26, 403-413. [CrossRef]

13. Guerci, A. L'ulivo tra scienza ed empirismo. Antrocom 2005, 1, 243-247.

14. Acerbo, G. La marcia storica dell'olivo nel Mediterraneo. Atti Soc. Prog. Sci. Riun. XXV 1937, 1, 1-22. 
15. Besnard, G.; Terral, J.F.; Cornille, A. On the origins and domestication of the olive: A review and perspectives. Ann. Bot. 2018, 121, 385-403. [CrossRef]

16. Castiglioni, E. I resti botanici. In Il Santuario dei Palici. Un Centro di Culto Nella Valle del Margi; Maniscalco, L., Ed.; Regione Siciliana, Assessorato dei Beni Culturali: Palermo, Italy, 2008; pp. 365-386.

17. Sadori, L.; Narcisi, B. The postglacial record of environmental history from Lago di Pergusa, Sicily. Holocene 2001, 11, 655-671. [CrossRef]

18. Terranova, F. L'insediamento dell'antica età del bronzo di Mursia e Pantelleria: Studio paleobotanico e paletnobotanico. In Apparati Musivi Antichi Nell'area del Mediterraneo: Conservazione Programmata e Recupero. Contributi Analitici Alla Carta del Rischio. Proceedings of the Convegno Internazionale di Studi La Materia e i Segni della Storia, Piazza Armerina, Italy, 9-13 April 2003; Flaccovio: Palermo, Italy, 2004; pp. 435-444.

19. Crispino, A. Castelluccio (Noto, SR). Notiziario di Preistoria e Protostoria; Istituto Italiano di Preistoria e Protostoria: Firenze, Italia, 2018; Volume 5, pp. 98-102.

20. Speciale, C.; Larosa, N.; Spatafora, F.; Calascibetta, A.M.G.; Di Sansebastiano, G.P.; Battaglia, G.; Pasta, S. Archaeobotanical data vs. present-day landscape patterns on the island of Ustica (Sicily, Italy): Radical changes in vegetation during prehistory? Environ. Archaeol. under review.

21. Costantini, L. Analisi paleoetnobotaniche nel territorio di Camarina. Boll. d'Arte 1983, 6, 49-56.

22. Cartabellotta, D.; Campisi, G.; Merra, A. Olivo in Sicilia. In L'ulivo e l'olio; Pisante, M., Inglese, P., Lercker, G., Bayer CropScience, Eds.; Collana Coltura\&Cultura; Script: Bologna, Italy, 2009.

23. Grant, M. The Visible Past: Greek and Roman History from Archaeology; Scribner's: New York, NY, USA, 1990.

24. Nenci, G. Le Tabulae Halaesinae: Alcuni problemi. In Colloquio alesino, Proceedings of Colloquio, Tusa, Italy, 27 May 1995; Prestianni Giallombardo, A.M., Ed.; Edizioni del Prisma: Catania, Italy, 1998; p. 112.

25. Schicchi, R.; Raimondo, F.M. I grandi alberi di Sicilia. In Azienda Foreste Demaniali della Sicilia; Collana Sicilia Foreste: Palermo, Italy, 2007; p. 312.

26. Wilson, R.J.A. Sicily under the Roman Empire. The Archaeology of a Roman Province. 36 BC-AD 535; Aris and Phillips: Warminster, UK, 1990.

27. Bazan, G.; Speciale, C.; Castrorao Barba, A.; Cambria, S.; Miccichè, R.; Marino, P. Historical Suitability and Sustainability of Sicani Mountains Landscape (Western Sicily): An Integrated Approach of Phytosociology and Archaeobotany. Sustainability 2020, 12, 3201. [CrossRef]

28. Castrorao Barba, A.; Speciale, C.; Miccichè, R.; Pisciotta, F.; Aleo Nero, C.; Marino, P.; Bazan, G. The Sicilian Countryside in the Early Middle Ages: Human-Environment Interactions at Contrada Castro. Environ. Archaeol. 2021. [CrossRef]

29. Primavera, M. Introduzione di nuove piante e innovazioni agronomiche nella Sicilia medievale: Il contributo dell'archeobotanica alla rivoluzione agricola araba di Andrew Watson. Archeol. Mediev. Cult. Mater. Insediamenti Territ. 2018, 45, 439-444.

30. Garnsey, P. Food and Society in Classical Antiquity; Cambridge University Press: Cambridge, UK, 1999.

31. Makhzoumi, J.M. The changing role of rural landscapes: Olive and carob multi-use tree plantations in the semiarid Mediterranean. Landsc. Urban Plan. 1997, 37, 115-122. [CrossRef]

32. Bazan, G.; Baiamonte, G.; Cancellieri, A.; Schicchi, R. BioCultural Landscapes per la rigenerazione innovativa dei territori di montagna. In Book of Abstracts XIX Conferenza Nazionale SIU—Cambiamenti Responsabilità e Strumenti per L'urbanistica al Servizio del Paese, Catania, IT, 16-18 June 2016; Planum Publisher: Roma, Italy; Milano, Italy; pp. 189-195.

33. Barbera, G. I paesaggi dell'olivo. In Olivo, Olivicoltura, Olio di Oliva: Guardando al Futuro: Dedicato a Franco Scaramuzzi; Alpi, A., Nanni, P., Vincenzini, M., Eds.; Polistampa: Firenze, Italy, 2021; pp. 23-35.

34. Agnoletti, M.; Emanueli, F. (Eds.) Biocultural Diversity in Europe; Springer International Publishing: Cham, Switzerland, 2016. [CrossRef]

35. Delgado, B.; Ojeda, J.F.; Amate, J.I.; Andreu, C. The olive groves of Andalucía and their distinctive landscapes of Mediterranean. Rev. Estud. Reg. 2013, 96, 267-291.

36. Schicchi, R.; Cordì, R.; Bazan, G. Primi dati sul progetto di censimento degli ulivi monumentali della Sicilia. Inform. Bot. Ital. 2005, 37, 162-163.

37. Schicchi, R. Due millenni di storia in 241 olivi monumentali. Inf. Agrar. 2006, 40, 10-11.

38. Lucchesi, T. Piano Stralcio di Bacino per l'Assetto Idrogeologico della Regione Siciliana; Regione Siciliana, Assessorato Territorio e Ambiente: Palermo, Italy, 2004.

39. Bazan, G.; Marino, P.; Guarino, R.; Domina, G.; Schicchi, R. Bioclimatology and vegetation series in Sicily: A geostatistical approach. Ann. Bot. Fenn. 2015, 52, 1-18. [CrossRef]

40. Barbera, G.; Cullotta, S. An inventory approach to the assessment of main traditional landscapes in Sicily (Central Mediterranean Basin). Landsc. Res. 2012, 37, 539-569. [CrossRef]

41. Assessorato Agricoltura e Foreste, Regione Siciliana. Allegato al PSR Sicilia 2007-2013. Analisi delle Principali Filiere Regionali. Available online: https:/ / www.psrsicilia.it/2007-2013/Allegati/Documenti/PSR_v8/05\%20PSR\%20Sicilia\%202007-2013\%20 v8\%20allegato\%204\%20-\%20Analisi\%20filiere\%20regionali.pdf (accessed on 20 March 2021).

42. ISTAT. Coltivazioni Agrarie-Anno 2019 (Roma: Istituto Nazionale di Statistica). Available online: https://www.istat.it/it/ agricoltura?dati (accessed on 28 March 2021).

43. Schicchi, R.; Bazan, G.; Marino, P.; Raimondo, F. I Grandi Alberi dei Nebrodi; CIRITA: Palermo, Italy, 2012. 
44. Schicchi, R.; Raimondo, F.M. Contributo alla conoscenza degli alberi monumentali delle Madonie (Sicilia centro-settentrionale). Nat. Sicil. 1999, 13, 229-314.

45. Michelakis, N. Monumental Olive Trees in the World, in Greece and in Crete. In Proceedings of the International Symposium, The Olive tree and olive oil in Crete, Sitia, Crete, Greece, 23-25 May 2002; pp. 23-25.

46. Arnan, X.; Lopez, B.C.; Martínez-Vilalta, J.; Estorach, M.; Poyatos, R. The age of monumental olive trees (Olea europaea) in northeastern Spain. Dendrochronologia 2012, 30, 11-14. [CrossRef]

47. Camarero, J.J.; Colangelo, M.; Gracia-Balaga, A.; Ortega-Martínez, M.A.; Büntgen, U. Demystifying the age of old olive trees. Dendrochronologia 2021, 65, 125802. [CrossRef]

48. Abbate, L.; Mercati, F.; Di Noto, G.; Heuertz, M.; Carimi, F.; Del Bosco, S.F.; Schicchi, R. Genetic distinctiveness highlights the conservation value of a sicilian manna ash germplasm collection assigned to Fraxinus angustifolia (Oleaceae). Plants 2020, 9, 1035. [CrossRef]

49. Giardinieri, A.; Schicchi, R.; Geraci, A.; Rosselli, S.; Maggi, F.; Fiorini, D.; Ricciutelli, M.; Loizzo, M.R.; Bruno, M.; Pacetti, D. Fixed oil from seeds of narrow-leaved ash (F. angustifolia subsp. angustifolia): Chemical profile, antioxidant and antiproliferative activities. Food Res. Int. 2019, 119, 369-377. [CrossRef]

50. Diez, C.M.; Trujillo, I.; Barrio, E.; Belaj, A.; Barranco, D.; Rallo, L. Centennial olive trees as a reservoir of genetic diversity. Ann. Bot. 2011, 108, 797-807. [CrossRef] [PubMed]

51. Calabrese, G.; Tartaglini, N.; Ladisa, G. (Eds.) Studio Sulla Biodiversità Negli Oliveti Secolari; CIHEAM-Istituto Agronomico Mediterraneo: Bari, Italy, 2012.

52. Salimonti, A.; Simeone, V.; Cesari, G.; Lamaj, F.; Cattivelli, L.; Perri, E.; Desiderio, F.; Fanizzi, F.P.; Del Coco, L.; Zelasco, S. A first molecular investigation of monumental olive trees in Apulia region. Sci. Hortic. 2013, 162, 204. [CrossRef]

53. Barazani, O.; Westberg, E.; Hanin, N.; Dag, A.; Kerem, Z.; Tugendhaft, Y.; Hmidat, M.; Hijawi, T.; Kadereit, J.W. A comparative analysis of genetic variation in rootstocks and scions of old olive trees-a window into the history of olive cultivation practices and past genetic variation. BMC Plant Biol. 2014, 14, 146. [CrossRef] [PubMed]

54. Anestiadou, K.; Nikoloudakis, N.; Hagidimitriou, M.; Katsiotis, A. Monumental olive trees of Cyprus contributed to the establishment of the contemporary olive germplasm. PLoS ONE 2017, 12, e0187697. [CrossRef]

55. Moreno-Sanz, P.; Lombardo, L.; Lorenzi, S.; Michelotti, F.; Grando, M.S. Genetic Resources of Olea europaea L. in the Garda Trentino Olive Groves Revealed by Ancient Trees genotyping and Parentage Analysis of Drupe Embryos. Genes 2020, $11,1171$. [CrossRef] [PubMed]

56. Ninot, A.; Howad, W.; Aranzana, M.J.; Senar, R.; Romero, A.; Mariotti, R.; Baldoni, L.; Belaj, A. Survey of over 4500 monumental olive trees preserved on-farm in the northeast Iberian Peninsula, their genotyping and characterization. Sci. Horticult. 2018, 231, 253-264. [CrossRef]

57. Cicatelli, A.; Fortunati, T.; De Feis, I.; Castiglione, S. Oil composition and genetic biodiversity of ancient and new olive (Olea europea L.) varieties and accessions of southern Italy. Plant Sci. 2013, 210, 82-92. [CrossRef]

58. Marra, F.P.; Caruso, T.; Costa, F.; Di Vaio, C.; Mafrica, R.; Marchese, A. Genetic relationships, structure and parentage simulation among the olive tree (Olea europaea L. subsp. europaea) cultivated in Southern Italy revealed by SSR markers. Tree Genetics Genomes 2013, 9, 961-973. [CrossRef]

59. Morettini, A. Olivicoltura; Ramo Editoriale degli Agricoltori: Roma, Italy, 1950.

60. Cancila, O. Baroni e Popolo Nella Sicilia del Grano; Palumbo: Palermo, Italy, 1983.

61. Baiamonte, G.; Domina, G.; Raimondo, F.M.; Bazan, G. Agricultural landscapes and biodiversity conservation: A case study in Sicily (Italy). Biodivers. Conserv. 2015, 24, 3201-3216. [CrossRef]

62. Marino, P.; Guarino, R.; Bazan, G. The Sicilian taxa of Genista sect. Voglera and their phytosociological framework. Flora Mediterr. 2012, 22, 169-190. [CrossRef]

63. Marino, P.; Geraci, A.; Schicchi, R. Notes on the karyology, genetics and ecology of Genista sect. Voglera in Sicily. Plant Biosyst. Int. J. Deal. All Asp. Plant Biol. 2012, 146, 324-329. [CrossRef]

64. Troia, A.; Bazan, G.; Schicchi, R. Micromorphological approach to the systematics of Mediterranean Isoëtes species (Isoëtaceae, Lycopodiophyta): Analysis of the megaspore surface. Grana 2012, 51, 35-43. [CrossRef]

65. Marino, P.; Schicchi, R.; Barone, E.; Raimondo, F.M.; Domina, G. First results on the phenotypic analysis of wild and cultivated species of Pyrus in Sicily. Flora Mediterr. 2013, 23, 237-243. [CrossRef]

66. Perrino, E.V.; Ladisa, G.; Calabrese, G. Flora and plant genetic resources of ancient olive groves of Apulia (southern Italy). Genet. Resour. Crop Evol. 2014, 61, 23-53. [CrossRef]

67. Perrino, E.V.; Wagensommer, R.P.; Medagli, P. Aegilops (Poaceae) in Italy: Taxonomy, geographical distribution, ecology, vulnerability and conservation. Syst. Biodivers. 2014, 12, 331-349. [CrossRef]

68. Geraci, A.; Amato, F.; Di Noto, G.; Bazan, G.; Schicchi, R. The wild taxa utilized as vegetables in Sicily (Italy): A traditional component of the Mediterranean diet. J. Ethnobiol. Ethnomed. 2018, 14, 14. [CrossRef]

69. Geraci, A.; Polizzano, V.; Schicchi, R. Ethnobotanical uses of wild taxa as galactagogues in Sicily (Italy). Acta Soc. Bot. Pol. 2018, 87, 3580. [CrossRef]

70. Prigioniero, A.; Geraci, A.; Schicchi, R.; Tartaglia, M.; Zuzolo, D.; Scarano, P.; Marziano, M.; Postiglione, A.; Sciarrillo, R.; Guarino, C. Ethnobotany of dye plants in southern Italy, Mediterranean basin: Floristic catalog and two centuries of analysis of traditional botanical knowledge heritage. J. Ethnobiol. Ethnomed. 2020, 16, 31. [CrossRef] 
71. Grassia, M.; Sarghini, F.; Bruno, M.; Cinquanta, L.; Scognamiglio, M.; Pacifico, S.; Fiorentino, A.; Geraci, A.; Schicchi, R.; Corona, O. Chemical composition and microencapsulation suitability of sumac (Rhus coriaria L.) fruit extract. Eur. Food Res. Technol. 2021, 247, 1133-1148. [CrossRef]

72. Blasi, C.; Carranza, L.; Di Pietro, R. Sistemi di paesaggio e recupero ambientale negli oliveti abbandonati nei monti Ausonii (Lazio meridionale). In Quaderno 6; Proceedings of the I ${ }^{\circ}$ Congresso Conservazione e Biodiversità nella Progettazione Ambientale, Perugia, 28-30 November 1996; IAED: Roma, Italy, 1997; pp. 51-57.

73. Biondi, E.; Biscotti, N.; Casavecchia, S.; Marrese, M. Oliveti secolari: Habitat nuovo proposto per l'inserimento nell'Allegato I della Direttiva (92/43 CEE). Fitosociologia 2007, 44, 213-218. 